\title{
Coming Soon
}

\section{University Libraries and Digital Learning Environments}

\author{
Edited by Penny Dale and Jill Beard, Bournemouth University, UK \\ and Matt Holland, North West Ambulance Service, UK
}

University libraries around the world have embraced the possibilities of the digital learning environment, facilitating its use and proactively seeking to develop the provision of electronic resources and services. The digital environment offers opportunities and challenges for librarians in all aspects of their work - in information literacy, virtual reference, institutional repositories, e-learning, managing digital resources and social media. The authors in this timely book are leading experts in the field of library and information management, and are at the forefront of change in their respective institutions. University Libraries and Digital Learning Environments will be invaluable for all those involved in managing libraries or learning services, whether acquiring electronic resources or developing and delivering services in digital environments.
Contents: Editors' introduction, Penny Dale, Jill Beard and Matt Holland; Here today and here tomorrow, Sue McKnight; It's all about social media, stupid!, Peter Godwin; Information literacy in the digital environment, Jacqui Weetman DaCosta; Professional education for a digital world, Sheila Corrall; The library chameleon: physical space, Liz Waller; Virtual advice services, Rachel Geeson; The reading evolution, Penny Dale and Jill Beard; Institutional repositories - now and next, Alma Swan; Making the repository count: lessons from successful implementation, Matt Holland and Tim Denning; Building useful virtual research environments: the need for user-led design, Melissa Terras, Claire Warwick and Claire Ross; The HE in FE digital dilemma, Jane Russ; Online support offered to international students by UK university libraries - what are we doing and why are we doing it?, Frank Trew; Library performance measurement in the digital age, Angela Conyers and Philip Payne; Library resources: procurement, innovation and exploitation in a digital world, Emma Crowley and Chris Spencer; Continuing professional development and workplace learning, Sheila Corrall; Librarians as midwives of change in scholarly communication, David Ball; Index.
To order, please visit: www.ashgate.com

All online orders receive a discount

Alternatively, contact our distributor: Bookpoint Ltd, Ashgate Publishing Direct Sales, 130 Milton Park, Abingdon, Oxon, OX14 4SB, UK Tel: +44 (0)1235 827730 Fax: +44 (0)1235 400454

Email: ashgate@bookpoint.co.uk
January 2011

c. 288 pages

Hardback

978-0-7546-7957-8

c. $£ 55.00$

This title is also available as an ebook, ISBN 978-0-7546-9897-5

For further information please visit

www.ashgate.com/ebooks 